KAPITEL 6

\title{
Vetenskapsakademien, samhället och makten
}

Om de föregående kapitlen vikts åt Vetenskapsakademiens idéer om samhället, dess politiska och ekonomiska ideologi, skall det följande ägnas åt sammanslutningens samröre med samhällsledningen. Detta undersöks med hjälp av teoribildningen kring karisma, som också används för att analysera presidietalens framställningar av akademiens roll i samhällsgemenskapen. Kapitlet är i huvudsak tematiskt upplagt och består av tre avsnitt, varav det första uppehåller sig vid Vetenskapsakademiens självbild och de två andra vid relationen till makten.

\section{Den samhällsnyttiga akademien}

Presidietalen betecknade ofta Vetenskapsakademien som ett samhälle. Den ansågs i linje med det ha lag, lagar och grundlagar precis som ett sådant. ${ }^{598}$ Ett frihetstida tal liknade rentav akademien vid en sorts idealsamhälle, då den var "et Samfund, hvars inrättning är så vis, och som i sin utöfning öfverträffar hvad en Plato[n] skulle förmodat". ${ }^{599}$ Flera gustavianska ledamöter laborerade med en lärd och en politisk gemenskap som i någon mån reflekterade varandra. De diskuterade den lärda och den politiska världen, och vetenskapliga och politiska samhällen som var fördelaktiga för människosläktet respektive endast beaktade sin egen nytta. Ett mer utvecklat resonemang kring de båda gemenskaperna återfinns hos Joachim Wilhelm Lilliestråle, som berörde "hvälfningar i lärdoms-verlden, som någorlunda likna, och äfven haft något sammanhang med dem i den politiska”. Han menade vidare att 
den goda myntstock som var högst nyttig för de samhälleliga rörelserna motsvarades av ett rikt språk i det lärda samfundet. ${ }^{600}$

En implicit parallellisering av den lärda och den politiska sfären kan skönjas i Bengt Bergius föreskrifter om vilka uppgifter som tillkom Vetenskapsakademiens sekreterare och preses. Sekreteraren, som jämfördes med pendeln i ett urverk, hade att bevaka stadgarnas efterlevnad, upprätthålla balansen mellan vetenskaperna, akta på ledamöterna och mana på dem som slutade dra sitt strå till stacken. Ordföranden skulle ge "lif och anda åt alla förrättningar, samt med upmärksamt öga hålla invärtes [inre] hushållningen i sitt rätta skick. Han har ock myndighet nog til Grund-Reglornas och all ordnings handhafvande". ${ }^{601}$ Bergius instruktioner till akademiens främsta funktionärer företedde påtagliga likheter med presidietalens framställningar av rikets styrande. Det tillkom bägge att kontrollera och driva på sina underlydande och att bevara jämvikten och ordningen i sitt samfund.

Enligt Dena Goodman hade de lärdas republik i likhet med statsmakten en diskursivt och institutionellt definierad politisk kultur, vilket gör det möjligt att tolka den som ett slags motpart till staten, "a polity parallel to the monarchy but entwined with it". ${ }^{602}$ Vetenskapsakademien jämställde som reflektionerna ovan visar i någon utsträckning den egna sammanslutningen och de lärdas republik med det omgivande samhället. Det är dock inte rimligt att dra alltför stora växlar på detta, eftersom ledamöterna stod i ett beroendeförhållande till samhällets mäktiga och säkerligen visste var den verkliga makten låg.

Naturforskare närmade sig samhällsledningen genom sociala nätverk, inom vilka deltagarna ömsesidigt iscensatte sig själva, samt genom sina ansträngningar i nyttans tjänst. Deras nyttiga arbete med såväl natur som hushållning gjorde att de kunde presentera sig som experter och medlare mellan den naturliga och den samhälleliga världen. Nyttoarbetet gav dem också ett betydande politiskt och socialt inflytande som tillät dem att uttala sig om hur samhället skulle ordnas; kunskap översattes till makt. ${ }^{603}$ Denna logik kom till uttryck i Vetenskapsakademien, som förenade natur- och samhällskunskap och brann för nyttigt vetande till Sveriges fromma - inte minst i presidietalen, där den ekonomiska patriotismen framträdde som "program och världsbild". ${ }^{604}$ 
Vetenskapsakademiens och ledamöternas gagneliga insatser utgjorde ett ledmotiv i de frihetstida talen. ${ }^{605}$ Akademien var den första inrättningen i sitt slag som genom sina grundlagar ålagt sig själv att fokusera på hushållningen och därmed associerade eller allmännyttiga vetenskaper. Organisationens intresse för praktisk nytta och allmänhetens håg för de publicerade rönen skilde den från andra akademier, och "ingen inrättning [hade], med mindre kostnad för Kronan och det allmänna, gjort bättre skäl för sig, än denna”. Ledamöter angav att sammanslutningen prioriterade svenskarnas nytta och nöje, ägnade sig åt samhällets fundament och satte det gemensammas väl högst; inga sysslor förutom dem som gynnade detta lovvärda syfte beaktades. Medlemmarna uppmanades att lägga all tid på att bistå sitt kära fädernesland och frambringa ymnigt med frukt till rikets båtnad. ${ }^{606}$ De gustavianska talen höll fast vid nyttotematiken. Vetenskapsakademien föreställdes som ett synnerligen nyttigt samfund, alltigenom uppfyllt av iver för det allmänna bästa. Sammanslutningens stora och ädla ändamål bestod i användbara vetenskapers uppodling, spridning och tillämpning med sikte på samhällets förbättring och välbefinnande. Akademien hade varit det första lärda sällskapet att vid sidan av "de höga vetenskaper" inlemma de eftersatta praktiska och nyttiga vetenskaperna, vilkas utveckling alltid legat ledamöterna varmast om hjärtat. ${ }^{607}$

Akademisekreterarens svar uppmärksammade ofta de avgående ordförandenas eller presidietalens nytta. ${ }^{608}$ Johan Carl Wilcke meddelade att den berömvärda sedvänjan att vid ordförandeskapets nedläggande ta upp ett för vetenskaperna och samhället nyttigt ämne så ofta givit nytt och viktigt stoff att samtiden inte utan anledning förde presidietalen till "de vackraste arbeten, hvarmed Academien bemödat sig för Efterkommande". ${ }^{609}$ Presides påpekade också nyttan av sina egna tal eller talen generellt. ${ }^{610}$ De uppgav bland annat att ett antal presidietal belyst något av värde för rikets väl, att ett par tal förmedlat åtskilligt till medicinalväsendets och allmänhetens nytta samt att medlemmarna var vana att vid bytet av ordförande trakteras med intelligenta anföranden som gav det allmänna uppbyggliga lärdomar. ${ }^{611}$

De många utsagorna om Vetenskapsakademiens allmännytta går att se som exponenter för karisma, inte minst utifrån idén att akademien 
befattade sig med samhällets fundament. Denna tolkning kan hämta stöd i ett annat genomgående tema, sammanslutningens patriotiska nit. ${ }^{612}$ Det hävdades att den frihetstida Vetenskapsakademien hölls samman av patriotism och drevs av kärlek till fäderneslandet, vars bästa utgjorde organisationens främsta ändamål och upplivade verksamheten; ledamöterna fann sanningen särskilt angenäm om den rörde rikets förbättring. ${ }^{613}$ Vetenskapsakademiens strävan efter nytta beskrevs som en självpåtagen skyldighet gentemot fäderneslandet att "på alt möjeligt sätt befordra dess vältrefnad" som varje medlem borde göra till sin plikt. Akademien fick en religiös sanktion när det gjordes gällande att Försynen skickat ledamöterna för att upplysa den svenska nationen om allt som hade med gemensamt väl att göra. ${ }^{614}$ Under gustaviansk tid hette det att Vetenskapsakademien frambar offer i "detta Vetenskaperne helgade Tempel, Fäderneslandet" och uteslutande brydde sig om Sveriges ära och medborgarnas nytta. Organisationen förnöjdes mest av fäderneslandets och vetenskapernas förbättring, och dess publikationer kännetecknades lika mycket av sann patriotism som av gedigen kunskap. ${ }^{615}$ Akademien kunde samtidigt framställas som en universalistisk institution, då den enligt uppgift osjälviskt verkade för att gagna mänskligheten och var till avsevärd nytta för såväl denna som fäderneslandet. En sammanslutning som Vetenskapsakademien skulle addera till Guds ära "jämte vårt Rikes, ja i vissa delar hela Människo-slägtets, redbara förmån". ${ }^{616}$

Betraktelserna ovan kan kopplas till medlemmarnas föreställningar om lärdomens välsignelser för Sverige, främmande länder och mänskligheten överlag. Konster och vetenskaper gestaltades som vägvisare till människans timliga lycksalighet som hade fått allmänt bifall, gjorde stor nytta i världen och syftade till allas väl samt vittnade om ett lands upphöjdhet och sällhet. ${ }^{617}$ Vetenskapsakademiens skrifter, exempel och ansträngningar hade övertygat om att vetenskaperna utgjorde grundvalen för ett rikes välmåga; samhällets styrka samvarierade med vetenskapernas uppodling och tenderade avta genom deras vanvård - det kunde inte bli lyckligt, beundrat eller föredömligt dem förutan. Det var därför en svår förbrytelse att behandla dem styvmoderligt, något som kontrasterades mot Vetenskapsakademiens förmånliga gärning och bedrifter. ${ }^{618}$ Ett par presidietal anmärkte att vetenskapen och Vetenskapsakademien 
förtjänade tacksamhet. Wilcke tog upp vetenskapernas nytta och "den förbindelse som Samhället är deras idkare skyldig”. Carl Rudenschöld menade att det inte anstod honom att redovisa vad det allmänna var förpliktigat akademien, som till skillnad från de flesta andra lärda sällskap inte belastade överheten genom personliga subsidier och ansåg sig nog belönad om den kunde vara till nytta. ${ }^{619}$

I några fall poängterades vetenskapens centrala roll för själva människoblivandet. Vetenskaper och konster hade avgränsat människan från resten av djuren och lärt henne att "göra jorden fruktsam, at taga skatter utur hårda Berg och djupa Haf, at försvara sig för [mot] öfvervåld, at bereda sig väg på sjelfva böljorna til de fjärmaste Länder: med et ord, at skaffa och tilreda [tillfredsställa] sina flästa behof". Vetenskaperna beskrevs som de rätta redskapen för människans förädling, vilka i samspel med ett upparbetat vett gjorde att hon stod över och rådde på djuren; med det vetenskapliga kunnandet kom makt över skapelsen. ${ }^{620}$

Kunskapens ekonomiska nytta åberopades av ett antal ledamöter, framför allt under frihetstiden. Presidietal förfäktade att vetenskapen ådagalade de bästa sätten att nyttja allting och att samtidens nya, fredliga och förbättringsorienterade "stats-klokhet" var oupplösligt förenad med dess upphjälpande: "hvar nu Vetenskaper och Konster florera, där finnes oförnekeligen allmänt välstånd; och hvar detta anträffas, där behöfver man icke vidare fråga efter tilståndet af de förre”. De inhemska näringarnas beaktansvärda tillväxt sammanföll med vetenskapernas nogsamma uppmuntran, medan handslöjderna förbättrades märkbart när de lärda omsatte sina kunskaper i praktiken. Mycket av okunskapens mörker hade jagats på flykten när genuin lärdom vunnit aktning och inflytande, och de "Ljus i Nationen" som tänt varandra skulle leda vägen och utveckla hushållningen med övriga invånares bistånd. ${ }^{621}$

Genom sin patriotiska nyttosträvan och nit och sitt arbete med vetenskaper av stort värde för riket fick Vetenskapsakademien en centralitet som gör att den kan definieras som en arena där karisma alstrades, i kraft av det nära och djupa sambandet med samhället och dess ödesfrågor. Akademien befann sig i samhällsgemenskapens mitt tillsammans med makthavarna, och idéerna om vetenskapens nytta för mänskligheten och roll för människoblivandet gav organisationen en ännu mer central 
position i tillvaron. Det ter sig mot bakgrund av detta som följdriktigt att de kunskapsägande framställdes i termer av en elit. Johan Browallius hävdade att de fåtaliga snillen som förbättrade och utökade näringarna var väsenligt större än sina landsmän och borde ha betydligt högre status än dem. En likartad ståndpunkt företräddes av Anders Johan von Höpken: "fä äro de, som äga Snille och kumskap [sic], få, som äro hugade åt en ofta otacksam Menighet at upoffra sin ro och sin hälsa. Få, som tro sig vara rikeligen belönte uti Samvetsro allena, och uti den enda förnöjelsen, at hafva fullgjordt sina plikter." ${ }^{22}$

Nils von Rosenstein förde ett ingående resonemang kring de lärdas medverkan i det politiska styret. Han uppgav att vetenskapens utövare inte hade del i regeringskonsten och ofta bedömts vara odugliga till offentliga ämbeten, vilket dock bara demonstrerade att teoretiska kunskaper var otillräckliga, inte att de var obehövliga eller onyttiga. Med rätt praktisk erfarenhet skulle tvärtom riktiga filosofer överträffa "vanans och erfarenhetens myndiga söner" och dem "som taga sin vana at befalla människor, sin slipning i verlden och umgänget för skicklighet; som af sin egen okunnighet döma til kunskapers onödighet”. Rosenstein drog utifrån det och Fredrik II:s av Preussen exempel slutsatsen att filosoferna borde vara regenter eller regenterna filosofer. Han fann också att de lärda tyglade, ledde och upplyste de styrande samt utgjorde källan till majoriteten av Europas konstitutionella förbättringar. Deras ansträngningar på det teoretiska planet innebar att de kunde dela makthavarnas ära och möda. Å andra sidan hängde ett rikes upplysning i första hand på styresmännens dito. Filosoferna skulle inte råda ensamma och var inte de enda som stod för upplysning inom politiken, där alla dygdiga och stora maktägande som sökte människornas lycksalighet fyllde samma funktion. Erfarenhet och praktiska göromål vägde tungt, och både teoretiker och styresmän kunde fara vilse. ${ }^{623}$ Rosensteins utläggning var trots dessa förbehåll det mest fullödiga uttrycket för akademiens syn på de lärda som en elitgrupp.

Vetenskapsakademiens nationella och internationella ryktbarhet framhölls i talen, huvudsakligen under frihetstiden, vilket ytterligare bidrog till att ge inrättningen en central symbolisk ställning. Den hade genom att inympa begåvade svenskar i "sin egen kropp [...] vunnit full 
styrka och hög aktning öfver hela jordklotet”. Europa gav dagligen prov på sin tacksamhet mot akademien, som värdesattes av alla lärda europeiska sällskap och tävlade med de yppersta bland dem. Det fanns knappt någon svensk som inte kände stolthet över sammanslutningens status $\mathrm{i}$ utlandet, vilket lovordade den, eftertraktade dess snillrika bragder och imiterade inriktningen på slöjder, handel och ekonomi. Fäderneslandet gladdes åt att organisationens ljus skyndsamt nått överallt och riktat blickarna mot Norden snarare än mot Italien. ${ }^{624}$ Olof Celsius tillskrev det internationella anseendet en metafysisk dimension när han höll före att Gud beskyddade Vetenskapsakademien och genom ledamöternas flit gjort den så pass prisad att organisationens skrifter begärligt efterfrågades söder om Alperna. Han avslutade sin redogörelse med en önskan om att akademien skulle fortsätta uppbära gudomligt stöd samt bli en rikets huvudpelare och prydnad för Norden. ${ }^{625}$ Gustavianska presidietal förklarade att Vetenskapsakademien på kort tid förvärvat den lärda världens respekt så att medlemskap blivit åtråvärt, och att akademiens glans sträckte sig lika långt som vetenskaperna. Högsinta män som brunnit för kunskaper och det allmänna bästa hade genom dess grundande tänt ett ljus som snart spritt sig till de mest fjärran trakter. ${ }^{626}$

Ledamöterna drog sig inte heller för att påtala Vetenskapsakademiens inrikes berömmelse. Frihetstidens akademi var hyllad och älskad i fäderneslandet, där allmänheten vant sig vid att få rön av mycket hög standard och uppskattade inte minst medlemmarnas lovvärda och nyttiga arbete. ${ }^{627}$ Under den gustavianska perioden uppmärksammades att svenskar gärna lyssnade på organisationens tal och att "Allmänhetens aktning, Europas lof-ord, höga Herrars gunst, Konungars Nåd och beskydd" alltid varit akademiens följeslagare. ${ }^{628}$

Ett antal presidietal berörde Vetenskapsakademiens befintliga eller framtida bedrifter. Frihetstida ordförande noterade att Handlingarna förmedlat åtskilligt nyttigt som annars nog aldrig skulle ha ådagalagts till det allmänna, samt att akademien gjort samlevnaden behaglig och böjt "hela folkhopen ifrån mörker til ljus, ifrån gissningar til sanningar, och ifrån onyttigt gräl til visdom". Landet skulle bli lyckligt om sammanslutningen snart avkastade sådana nyttiga frukter som svarade mot medlemmarnas ambitioner. Mest långtgående var Carl Gustaf Löwen- 
hielm, som slog fast att samtiden genom Vetenskapsakademien under loppet av två årtionden skapat mer ekonomisk kunskap än några av de föregående århundradena. ${ }^{629}$

Dessa utsagor implicerade i likhet med yttrandena om akademiens ryktbarhet att organisationen utgjorde en central punkt i tillvaron. De blev något färre i de gustavianska presidietalen, som meddelade att Vetenskapsakademiens föredöme låg till grund för Sveriges berömvärda lantbrukssällskap, att Handlingarna bidragit avsevärt till att förbättra huvudnäringen jordbruket samt att akademien och Jacob Faggot spelat en avgörande roll för skiftesreformen, som med tanke på sin framgång och nytta torde sakna motstycke i de ekonomiska krönikorna. Carl Christopher Arfvedson uppgav att ledamöternas arbete och exempel

haft de lyckeligaste fölgder. De til Samhällets välgång och förkofran mäst ländande kunskaper äro satte i sin fulla dag; flere skadeliga fördomar och falska begrepp om den allmänna hushållningen, hvilka förledt Allmänheten och ofta verkat de största misstag i författningarna, äro försvundne. Hvad kan för et Folk vara angelägnare, än allmän uplysning och sunda begrepp, fotade på osvikeliga grunder i de vetenskaper, som närmast leda til allmänt väl och enskild båtnad? Hvad kan för goda Medborgare vara mera tilfredsställande, än at därtil bidraga?630

Wilckes svar till Arfvedson bekräftade talets verklighetsuppfattning. Han lyfte fram att Vetenskapsakademien alltsedan 1739 fokuserat på verkligt allmännyttiga konster och vetenskaper - däribland hushållningen och handeln - som den på alla sätt sökt stärka, jämte fliten. Genom denna orubbliga hängivenhet befordrades Sveriges väl. Sammanslutningen hade haft lyckan att i detta sitt värv alltid vara lierad med "Män, hvilkas mogna erfarenhet, stadgade insigt och rena nit för allmänt väl, på mångfallt sätt gagnat, stadgat och förkofrat så väl Academiens egen varelse, som framgång af Dess nyttiga föremål [ändamål]”. Wilcke illustrerade den typen av individer med namn som Jonas Alströmer, Faggot och Niclas Sahlgren, som sades göra vidare kommentarer överflödiga. ${ }^{631}$ Hans uppräkning visar hän mot Vetenskapsakademiens approprieringar av 
samhällsledningen, vilka liksom de ovan analyserade föreställningarna om akademien fick den att framstå som en central och karismatisk arena.

\section{Approprieringar och smicker}

Vetenskapsakademien tenderade i samband med sina närhetsmarkeringar till makthavare och representanter för eliten att uppvärdera dem för maximal effekt. Akademien var visserligen en aktör i egen rätt, men kom genom approprieringarna av samhällsledningen att ta del av dess karisma och även på denna väg inta en central bildlig ställning i den sociala och politiska gemenskapen. De nära kontakterna med eliten och makthavarna framgick tydligt i presidietalen, inte minst genom att uppräkningar av bemärkta ledamöter omfattade ämbetsmän, politiker och politiskt inflytelserika näringsutövare. Rosenstein den yngre nämnde att flera förutvarande presides hade fått honom att blygas när han tillträdde sitt ordförandeskap - "LINNÉER, KLINGENSTJERNOR, POLHEIMAR, WALLERIER, TESSINER och EHRENSWÄRDAR". Olof Swartz riktade strålkastarljuset mot strävsamma medborgare som i det gemensamma bästas tjänst utforskat naturens ekonomi under frihetstiden och som eftervärlden aldrig borde glömma bort. Bland dem återfanns akademimedlemmar av samhällsledande slag, som Jonas Alströmer, Carl Wilhelm Cederhielm och Löwenhielm, jämsides med lärda ledamöter. Samuel Sandels förtecknade ett antal avlidna medlemmar för att åskådliggöra att Sverige kunde mäta sig med andra upplysta länder ifråga om konster och lärdom. På hans lista stod inte bara lärda som Anders Celsius och Samuel Klingenstierna utan också samhällsledande personer som Claes Grill, Carl Hårleman och Carl Gustaf Tessin. Till dem som gjort särskilt betydande insatser för Vetenskapsakademien räknade Sandels exempelvis Alströmer, Celsius, matematikern och akademisekreteraren (1744-49) Pehr Elvius, Grill, Hårleman och Carl von Linné. ${ }^{332}$

Vetenskapsakademiens band till statsmakten diskuterades emellanåt i talen. En ordförande informerade om att han å akademiens vägnar uppvaktat "Högre orter" och hoppades på ett förmånligt utfall av detta. En annan fäste blicken på sammanslutningens funktion som statlig 
remissinstans när han förkunnade att Kongl. Maj:t och ständerna hyste så stort förtroende för Vetenskapsakademien att de utbad sig om ett omdöme varje gång något ärende föll inom ramarna för organisationens kompetenser. I ett sammanhang beskrevs ledamöterna som "högt uplyste Herrar och män, hvilkom af högre ort är blifvit anförtrodt, at uptänka och författa medel til et genare och det allmänna gagnande upfostringssätt". ${ }^{633}$

Presidietalen innehöll en rad uppgifter om donationer till Vetenskapsakademien från samhällets övre skikt, kungligheterna och ständerna. ${ }^{634}$ Gåvorna förklarades möjliggöra för akademien att ära nyttiga rön, uppmuntra lärda och inspirera till förmånlig konkurrens. I samband med att "en ädelmodig Medborgare" skänkt akademien ett rundligt belopp för jordbrukets förbättring reflekterades det över hur organisationen eggades "på alt sätt, med Nåd ifrån Thronen, med välvilja på alla sidor". Varken en nådig överhet eller välvilligt inställda medborgare hade dröjt med att stötta sammanslutningen, som raskt konsoliderats och förhoppningsvis skulle bli än mer blomstrande med tanke på sina mecenaters gunst. ${ }^{63}$ Enligt Sandels hade Vetenskapsakademiens välgörare varit viktiga för verksamheten och skänkt substantiella belopp. Akademien uppbar räntan på det kapital rådmannen Sebastian Tham avsatt till offentliga vetenskapsföreläsningar, som en favör från hans arvingar och Riddarhuset, vars direktion var vänligt stämd till organisationen. Konungen, Stockholms stads magistrat och hedervärda medborgare som Claes Grill gav generösa summor till Vetenskapsakademiens astronomiska observatorium, medan andra försåg den med instrument, böcker och naturalier. Bland de senare märktes Fredrik Sparre, som av kärlek till vetenskaperna lämnade akademien sin kvarlåtenskap och liksom Tham fick en medalj (jetong) slagen över sig. ${ }^{636}$

Framställningarna av mecenatskapen var i flera fall analoga med Vetenskapsakademiens gestaltningar av samhällsledningen som drivande i den ekonomiska och sociala utvecklingen. Pehr Wilhelm Wargentin ansåg det vara nobelt och berömvärt att välborna och respekterade män vinnlade sig om vetenskaperna och vetenskapsmännen. Han framhävde vikten av de många engagerade mecenater som understött goda ansatser, uppmuntrat begåvningar och förstått att få fram mogna frukter hos 
dem som besuttit lovande frön; mecenaternas gärning inspirerade till ädel tävlan, försatte allt i rörelse och gjorde så att konster och vetenskaper grönskade. De som lade mycken möda och dryga kostnader på att upprätta mineraliesamlingar var lika relevanta som de som visste att ordna och begagna sig av samlingarna. Akademien häftade följaktligen i tacksamhetsskuld till åtskilliga medborgare utöver sina grundare och medlemmar. ${ }^{637}$

Höpken uppehöll sig vid dem som givmilt bistått Vetenskapsakademien och vid de rikliga förmåner som kommit den till del, inte minst Grills och Riddarhusets bidrag till observatoriebyggandet. Det gick inte an att negligera akademiens "odödeliga förbindelser [...] emot vissa Herrar och Män" som gynnat observatoriet och därför alltid borde uppbära tacksamhet. Han fastställde härvidlag att vetenskaperna får liv genom uppmuntran och att Försynen ibland väcker upplysta och ansedda personer - mänsklighetens prydnader, efterkommandes förebilder - som stimulerar kunskap och förnuft. De mäktigas understöd identifierades i linje med detta som huvudorsaken till vetenskapernas lyckliga tillstånd i samtiden. ${ }^{638}$ Ett snarlikt perspektiv anlades av Bengt Bergius:

Magnater eller höga Herrar äga altid en mägtig kraft til Vetenskapers främjande i margfallig [mångfaldig] måtto, synnerligen genom det [att] de hägna, upelda och underhjelpa deras nitiska, och merendels betryckta, stundom ock försagda, idkare. Lyckeligt, när sådane Herrar tillika fått nog insigt i dessa fria konster, för at förstå deras rätta dyrd [dyrbarhet], ty då saknas aldrig omtankan och viljan at befordra deras upkomst, kunnandes tilfällen dertil gifvas många. Så sinnade Magnater kunna visserligen, utan minsta arbetsamma åtgärd på sjelfva Lärdoms-fältet, obeskrifveligen gagna ett Vetenskaps-Samhälle, med hvilket de sig förbinda, ty de göra dess ädla tänkesätt gällande genom det kraftiga intryck de verka hos Allmänheten med sin upmuntrande föresyn, de pryda och uplifva sammankomsterna med sin flitiga närvarelse, de gifva eftertryck åt författningarna [stadgarna] med sitt anseende, och de uprätthålla ordning medelst sin myndighet. För öfrigt kunna de ofta ogement bidraga til en Vetenskaps framsteg, genom någon dess Idkares [upp]muntrande och framdragande i rättan timma. 
Den sista tesen belystes med hjälp av naturalhistorien och Linné, vilken tack vare magnater och mecenater kunnat följa sin håg och förbättra vetenskapen han älskade. ${ }^{639}$

Vissa resonemang kring donationer och mecenatskap var framåtblickande och kan därmed misstänkas ha syftat till övertalning. Anders Sparrman lyfte fram Vetenskapsakademiens erkänsla mot höga välgörare som Carl Albrecht Rosenadler och Ulric Scheffer, vilkas gåvor med säkerhet skulle föranleda fler. Han lovade att beständigt nedteckna donatorernas namn så att de skulle förbli ihågkomna och hedrade. Bengt Bergius uppgav att akademien, som nått framgång utan skattemedel eller "synnerligt uplyftande genom Öfverhetens arm", tacksamt drog sig till minnes alla ynnestbevis och på senare tid sett medborgare nästan konkurrera med varandra om att stödja organisationen. Denna tävlan skulle med största säkerhet fortgå och ett sådant bakvänt tänkande troligen aldrig kunna uppstå att "Magnater skola finna sig förmörkade af något nedlåtande ibland lärda, fast mindre lysande, Män". ${ }^{640}$

Det frihetstida kungahusets kontakter med Vetenskapsakademien uppmärksammades ofta före det rojalistiska statskuppsförsöket 1756. Ledamöter diskuterade "de dyra Ljus" som ärade akademien med uppmuntran och beskydd och det förtroende sammanslutningen åtnjöt hos sin nådiga överhet. ${ }^{641}$ Fredrik I figurerade vanligen tillsammans med kronprinsen Adolf Fredrik. Det kungliga stödet angavs ha förstärkt Vetenskapsakademien påtagligt och gjort att den kunnat etablera värdefulla utländska kontakter. Kongl. Maj:ts och kronprinsens beskydd hölls för att manifestera Guds vilja, och akademien skulle allt framgent betrakta det som en förmån utan motstycke och prisa Adolf Fredriks nåd, som "högre Samfund ej ens våga sig at äska". ${ }^{642}$ Carl Didrik Ehrenpreus gjorde gällande att lärda sällskaps existens var beroende av furstens beskydd och styrka, varför akademien aldrig nog kunde lovorda Fredrik I:s höga tankar och stora avsikter. Fredrik hade gunstigt stadfäst Vetenskapsakademien, varefter Adolf Fredrik av kärlek för den blivit dess medlem och även tagit på sig rollen som skyddsherre för att öka uppmuntran av vetenskaperna, konsterna och slöjderna, välfärdens och lycksalighetens enda grunder. Ehrenpreus yrkade på kraftsamling "til en så huld och nådig Konungs nöje: til en så ädel Arf-Furstes hugnad 
och glädje: til en så vördnads värdig mild Prinsessas [Lovisa Ulrika] längtan och åstundan och til Svea Hopps fägnad”. Talet registrerade att Adolf Fredrik deltog i den aktuella sammankomsten och att han för första gången bevistat akademien under Ehrenpreus presidium, samtidigt som kronprinsparet och deras son Gustav porträtterades som den svenska lärdomens garanter. ${ }^{643}$

Carl Fredrik Piper konstaterade efter Fredrik I:s frånfälle att vetenskaperna hade revitaliserats och Vetenskapsakademien tagit sin gudabenådade början under hans styre. Eftersom monarken godkänt stadgarna och skänkt akademien dess "första styrka" var ingenting skäligare än att den visade sin vördnad vid hans grav. Piper växlade därpå över till att hylla den nye konungen, som utfäst sig att förbli Vetenskapsakademiens skyddsherre. Wargentins svar till Piper betonade liksom talet inrättningens band till både Fredrik och efterträdaren Adolf Fredrik, vilken upptagits som ledamot, gjort akademien till sin egen och skänkt den nytt liv genom sitt beskydd. Såväl vetenskapernas och Vetenskapsakademiens mognad och blomstring som rikets bestående sällhet var att vänta av hans regeringstid. ${ }^{644}$

Adolf Fredrik blev än mer approprierad efter sitt trontillträde. Konungen sades ha nedstigit från tronen och tagit säte i akademien så att vetenskaperna fick nödvändigt beskydd och kom till rätt användning. Hans "visa styrsel och öma omvårdnad" utgjorde sammanslutningens "Lif och Styrka". Medlemmarna gladde sig åt den kungliga omvårdnaden och tog del av dess ljuvligaste frukter. Det ålåg dem att bära fram säkra och klara nyttouppslag till den milde landsfadern, som sedan skulle tillämpa deras idéer. Carl Fredrik Scheffer parallelliserade politik och lärdom när han anförde att regentens övertygelse om välfärdens nära samband med vetenskaper och konster fått honom att bli Vetenskapsakademiens huvud, varigenom Sveriges och vetenskapernas styren förenades och upplivades av en anda. ${ }^{645}$

Den mest långtgående approprieringen av Adolf Fredrik påträffas hos Höpken, som förklarade att monarkens deltagande gjorde dagen då Vetenskapsakademiens astronomiska observatorium invigdes alltigenom härlig. Akademien hade önskat och fått njuta nåden av sin skyddsherres närvaro, som stimulerade vetenskaperna och bringade riket lycka. Sam- 
tidigt framhölls Adolf Fredriks allmänna medverkan i organisationens verksamhet: "Vi hafve sedt, Mine Herrar! den sitta ypperst ibland Oss, som Försynen och Ständers val satt ypperst öfver folket. Vi hafve sedt vår Konung taga sit säte ibland Vetenskaper och dess idkare, ibland åtskillige arter af Snilles-gåfvor.” Höpken pekade på den positiva effekt en upplyst överhets beskydd hade på Vetenskapsakademien och frågade retoriskt om några varit mer gynnade av konung och riksdag än ledamöterna. Även Lovisa Ulrika smickrades och knöts till akademien, ${ }^{646}$

Som framgått av det föregående kapitlet marginaliserades kungligheterna i presidietalen efter det misslyckade statskuppsförsöket 1756. Samma mönster kan urskiljas med avseende på Adolf Fredriks beskydd, som väsentligen kom att förbigås med tystnad fram till 176o-talets slut. De enda som dessförinnan kommenterade hans förhållande till Vetenskapsakademien var Carl Knutberg, som nämnde konungens status av skyddsherre, och Wargentin, som delvis knöt sammanslutningens framgångar till den höga överhetens gunst. ${ }^{647}$ En appropriering av Adolf Fredrik i samma stil som före kuppstämplingarna infann sig först på hösten 1769, när kungaparets allierade hattarna segrat på riksdagen och John Jennings diskuterade den nåd akademiens beskyddare visat när han upplåtit ett hus till organisationen. Vetenskapsakademien hade avgivit den mest underdåniga tacksägelse och försäkran om fortsatt strävan efter att förverkliga syftet med Kongl. Maj:ts omtanke - "Samtidas och Efterkommandes väl, igenom ljus och kunskaps utspridande". Jennings inflikade dock att sekreta utskottet, alltså ständerna, hemställt om den kungliga favören. Han beskrev vidare hur kungafamiljen, i synnerhet Lovisa Ulrika, hedrat de hädangångna ledamöterna Dalin och Klingenstierna, vilket föranlett akademien att betyga sin vördnad genom präglandet av ett par medaljer. ${ }^{648}$

Wargentins svar till Jennings noterade att dennes presidium kännetecknats av högst angenäma händelser och varit lyckosamt för Vetenskapsakademien. Sekreteraren åberopade i likhet med Jennings ständerna, vilka givit röst åt sin uppskattning av sammanslutningens verksamhet. Svaret smickrade också hatten Jennings, som meddelades ha agerat till akademiens fromma i sekreta utskottet, genom att framföra att hans ordförandeskap inlett en ny epok i organisationens historia. ${ }^{649}$ 
Det var av allt att döma viktigt att inte ensidigt hylla monarkerna och att balansera dem mot riksdagen och hattpartiet.

Approprieringarna av Adolf Fredrik överlevde hans död. Carl Johan Cronstedt tillkännagav en tid efter hans frånfälle att inget av Vetenskapsakademiens systersällskap haft större orsak till erkänsla eller smärtsammare grund för sorg. Fäderneslandet sörjde en välvillig och patriotisk far, akademien en vetenskapsälskare, hög ledamot och aktad beskyddare. Ledamöterna mindes tacksamt hur kronprinsen Adolf Fredrik "ej ansåg dessa Titlar vara under Dess [sin] värdighet, ej [h]eller sedermera trodde Thronen däraf kunna fördunklas", vilket gjorde att han inte lät sitt engagemang stanna vid det formella. Vetenskapsakademien hade frekvent haft anledning att uppskatta hans förtroende och dess synpunkter upprepade gånger bemötts med respekt. Vetenskaperna hade frodats under ett beskydd som skulle få Adolf Fredrik att gå till historien som Cosimo de Medicis och Ludvig XIV:s like. Wargentins svar behandlade utöver medlemmarnas sorg och den döde konungens förhållningssätt till akademien efterträdaren Gustavs intresse för vetenskaper och konster, liksom hans förmåga att befordra dem. ${ }^{650}$

Den blivande Gustav III associerades tidigt med Vetenskapsakademien. Det gjordes gällande att varken akademien eller fäderneslandet skulle sakna styrka eller glädje så länge Försynen lät det nyfödda kronprinsbarnet "tilväxa i en grönskande Sällhet". Som nybliven regent utökade Gustav akademiens lokaler, vilket framställdes som en lycklig början, ett nådebevis och ett tecken på fortsatt kungligt beskydd. ${ }^{651}$

Sandels uppgav att både Gustav III och Vetenskapsakademien sörjde förlusten av Adolf Fredrik och att den nye furstens liv var sammanflätat med akademiens: "Imellan dem, som på en [vid samma] tid upväxa, under en och samma tilsyn, knytes ofta i spädare åren ett band, som i den tilkommande tiden hvarken höghet, eller myckenhet af omsorger förmå uplösa." Sammanslutningen hade i förskräckelse över sin beskyddare Adolf Fredriks bortgång vänt sig till hans arvtagare, och det med fullständig förtröstan eftersom den nye konungen ännu mera än sin företrädare strålat av kärlek till vetenskaperna, de fria konsterna och hushållningen. Ledamöternas lycka över att Gustav tagit på sig rollen som organisationens skyddsherre hade sedan hållits vid liv genom kunglig 
uppmuntran. Hans regering skulle bli mer lysande än någon annans och vittne till akademiens framsteg. ${ }^{652}$ Sandels fastslog att monarkers omtanke varit mer betydelsefull än donatorer för Vetenskapsakademien, som behövde kungligt godkännande och beskydd. Samme ordförande skildrade de två föregående regenternas, främst Adolf Fredriks, insatser för akademien och delaktighet i dess verksamhet. Han riktade sig direkt till Gustav med utsagan att en inrättning som existerade för rikets skull och hedrats med så upplysta och nådiga monarkers uppmärksamhet tillhörde konungen. ${ }^{653}$

Redogörelsen för företrädarnas gynnsamma inställning kan tolkas som ett försök att pådyvla den unge monarken en fördelaktig och aktiv hållning till Vetenskapsakademien, speciellt med tanke på att Sandels tilltalade och vävde in honom i sin utblick. En liknande ansats kan skönjas i Wargentins svar, vilket framhävde akademiens åtnjutande av regenters utmärkta nåd och den nye beskyddarens "med Blodet ärfda och genom egen uplyst öfvertygelse förvärfvade höga ynnest för Vetenskaper”, som bådade gott inför framtiden och skulle addera till organisationens lycka. ${ }^{65}$

Konung Gustav III:s första besök vid Vetenskapsakademien högtidlighölls i ett tal av Carl Rudenschöld som hade denna begivenhet till ämne. Rudenschöld lyfte fram Gustavs ställning som beskyddare och akademiens tacksamhet, underdånighet och tillfredsställelse över att regenten ärade mötet med sitt deltagande. Talet angav att ledamöterna strävade efter att vara honom värdiga och göra sig förtjänta av hans nåd, som de hoppades få fortsätta ta del av. ${ }^{655}$ Den nådige skyddsherren Gustav och hans hedrande närvaro liksom Vetenskapsakademiens känslor inför den återkom i flera presidietal i begynnelsen av det gustavianska tidevarvet. ${ }^{656}$ Tematiken utbroderades på olika sätt. Till exempel var Gustav, enligt Nils Rosén von Rosenstein som vände sig direkt till honom, inpräntad i hjärtat hos alla ledamöter som värdesatte vetenskaper och visste vad konungen gjorde för dem. Det skulle bli lätt för medlemmarna att verka under en regent som redan före sin tronbestigning värnat vetenskaperna och oaktat sin börd bedömts vara kungamakten värdig. ${ }^{657}$

Gustav III återgäldade Vetenskapsakademiens smicker och approprie- 


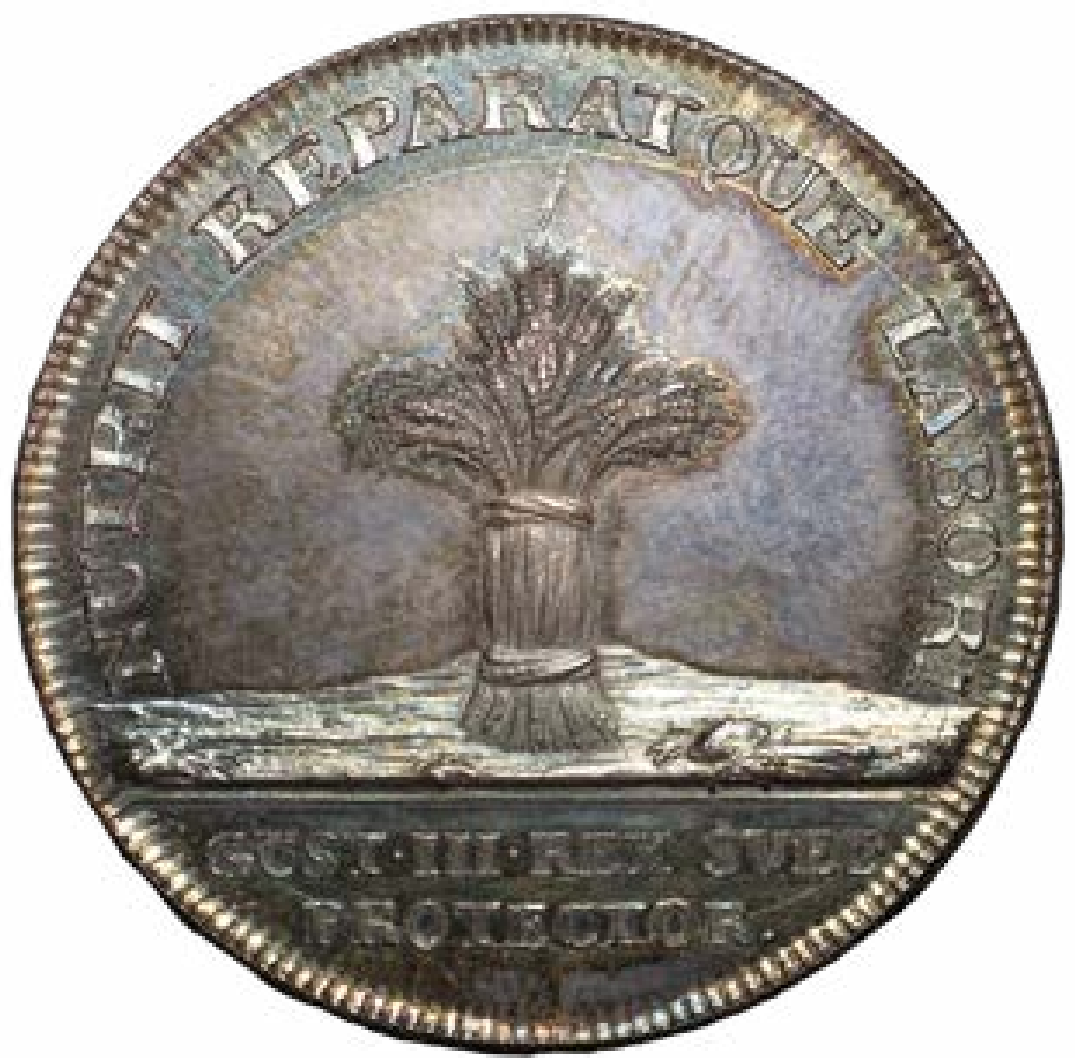

Bild 11. Gustaf Ljungberger, medalj slagen för att högtidlighålla att Gustav III blev Vetenskapsakademiens beskyddare 1771. Foto: Uppsala universitetsbibliotek.

ringar i ett svar till Rudenschöld, där han tydligt sökte bekräfta bilden av sig själv som en vetenskapsfurste i Fredrik I:s och Adolf Fredriks efterföljd. Konungen beskrev akademien som en allmännyttig, framgångsrik och för fäderneslandet ärofull institution. Han betygade inte endast sin välvilja och sitt beskydd, utan klargjorde även att han avsåg att sätta sig in i dess arbete, tillägna sig kunskaper genom att närvara vid sammankomsterna samt uppmuntra vetenskaperna med sitt exempel. ${ }^{658}$

Närhetsmarkeringarna till Gustav III fortgick med oförminskad styrka efter statsvälvningen, som sades innebära ljusare utsikter för 
Vetenskapsakademien än någonsin förr ${ }^{659}$ Det fastslogs att konungen i sitt beskydd av olika institutioner hade ett särskilt öga till akademien, vilken han såg som en juvel i sin krona. Sammanslutningen värdesatte att han fungerade som dess skyddsherre och gjorde sig hoppfullt förvissad om att relationen skulle bestå så länge naturens lagar tillät. Vetenskapsakademien hade fått så många nådebevis att bara deras förtecknande riskerade upplevas som inställsamt. Ingen hade erfarit Gustavs stimulerande verkan mer än hans akademi och ingen var mer förpliktigad att kombinera sina tacksamhetsyttringar med trofasta önskningar om hans sällhet. Organisationen presenterades därutöver som en katalysator för kunglig kraft - alltså karisma: "de lifligaste strålar ifrån sjelfva Konunga-Thronen blifva hitspridde, [för] at, sedan de här gifvit full dag, med fördubbladt återsken falla tilbaka på sit ursprung, den klara och välgörande Solen, at så mycket kraftigare lysa, gagna och uplifva det allmänna". ${ }^{600} \mathrm{I}$ ett tal inbegrep markerandet av närhet till monarken hans efterträdare, då ledamöterna bad för en kronprins och framtida skyddsherre med samma gynnsamma egenskaper som glänste på Gustavs tron. ${ }^{661}$

Konungens medverkan vid mötena förblev ett ledmotiv i presidietalen. Ledamöter menade att inget annat vetenskapssamhälle i så hög grad torde kunnat förnöja sig över sin överhets närvaro och att de inte var tillräckligt vältaliga för att uttrycka Vetenskapsakademiens tillfredsställelse över sin skyddsherres hedrande deltagande i sammankomsterna. Både akademien och riket gladde sig över regentens beskydd av vetenskaperna, men hans besök gjorde organisationens glädje än större; de skedde ofta på hans vilotid och hade en såväl uppmuntrande som statushöjande effekt. Carl Rudenschöld kommenterade Gustav III:s närvaro vid det möte där han avgick, och hävdade att sammanslutningen var ensam i sitt slag om att beskyddas av en upplyst domare som inte ansåg det under sin värdighet att lägga tid på den. Denna ära krävde desto mera av Vetenskapsakademien och gav näring åt en strävan att göra Gustavs regering strålande och vördnadsfullt ihågkommen. ${ }^{662}$

De teman som präglade beskrivningarna av Gustav III:s förhållande till Vetenskapsakademien gick igen efter hans död. Zacharias Zachariae Plantin framställde konungen som en vetenskapernas vän, som bistått 
snillen, ärat dem som förenat patriotism, flit och utvecklade kunskaper samt månat om att stimulera upptäckten av nya sanningar och kanalisera redan kända sådana i rätt riktning. Akademien hade alltid varit en älskad mottagare av den saknade beskyddarens omsorg och Gustav hade vid flera tillfällen hedrat sammankomsterna med sin närvaro. Wilckes svar fortsatte på det inslagna spåret. Sekreteraren uppehöll sig vid den stora förlusten av en välvillig furste, som resolut kopplades till organisationen:

Detta Hus, som GUSTAF sjelf til boning för dem [vetenskaperna] utsett: med Sin höga Närvaro dertil helgat och ofta hedrat: - Detta Bord, hvarvid GUSTAF Sjelf tagit säte och öfvervarit Våra Högtider och Våra öfverläggningar: - Academiens Samlingar, prydde med Kongl. gåfvor af Dess [hans] Hand: - Academiens förmögenhet, riktad [berikad] af Dess gynnande Nåd: - Våra Arbeten, nådigt gillade, nådigt öfversedde: - Alt detta, och mycket mera, påminner om och framkallar Vår sorg, Vår saknad, Vår innersta känsla af mistning; framkallar Minnet af en vördad och älskad SKYDDSHERRE, en KONUNG, Hvars Majestät äfven spridt välgörande strålar til denna Vetenskapernas inskränktare krets. ${ }^{663}$

Tyngdpunkten kom nu att överföras på den omyndige Gustav IV Adolf. Plantin deklarerade att Vetenskapsakademien skulle fortsätta att utforska och förmedla nyttiga sanningar under dennes beskydd, Wilcke att akademien troget förlitade sig på den dyrbare unge regenten och på kungahuset, utan vars beskydd "bästa viljan stadnar i kraftlöst bemödande". ${ }^{664}$ Detta visar, liksom utsagorna om Adolf Fredriks livgivande verkan och solen Gustavs strålar, på Vetenskapsakademiens smak för och anammande av kunglig karisma.

Under frihetstiden positionerade sig akademien av uppenbara skäl också nära riksdagen. Presidietal meddelade att inga var mer gynnade av de höglovliga ständerna än ledamöterna och att den gunst Vetenskapsakademien åtnjöt framgick av bland annat att sammanslutningen fått äran att publicera Tessins korrespondens med kronprins Gustav. Riksdagen bidrog till uppförandet av det astronomiska observatoriet och ständernas manufakturkontor avsatte jämte andra offentliga institutioner på akademiens inrådan ansenliga medel till medlemmen, 


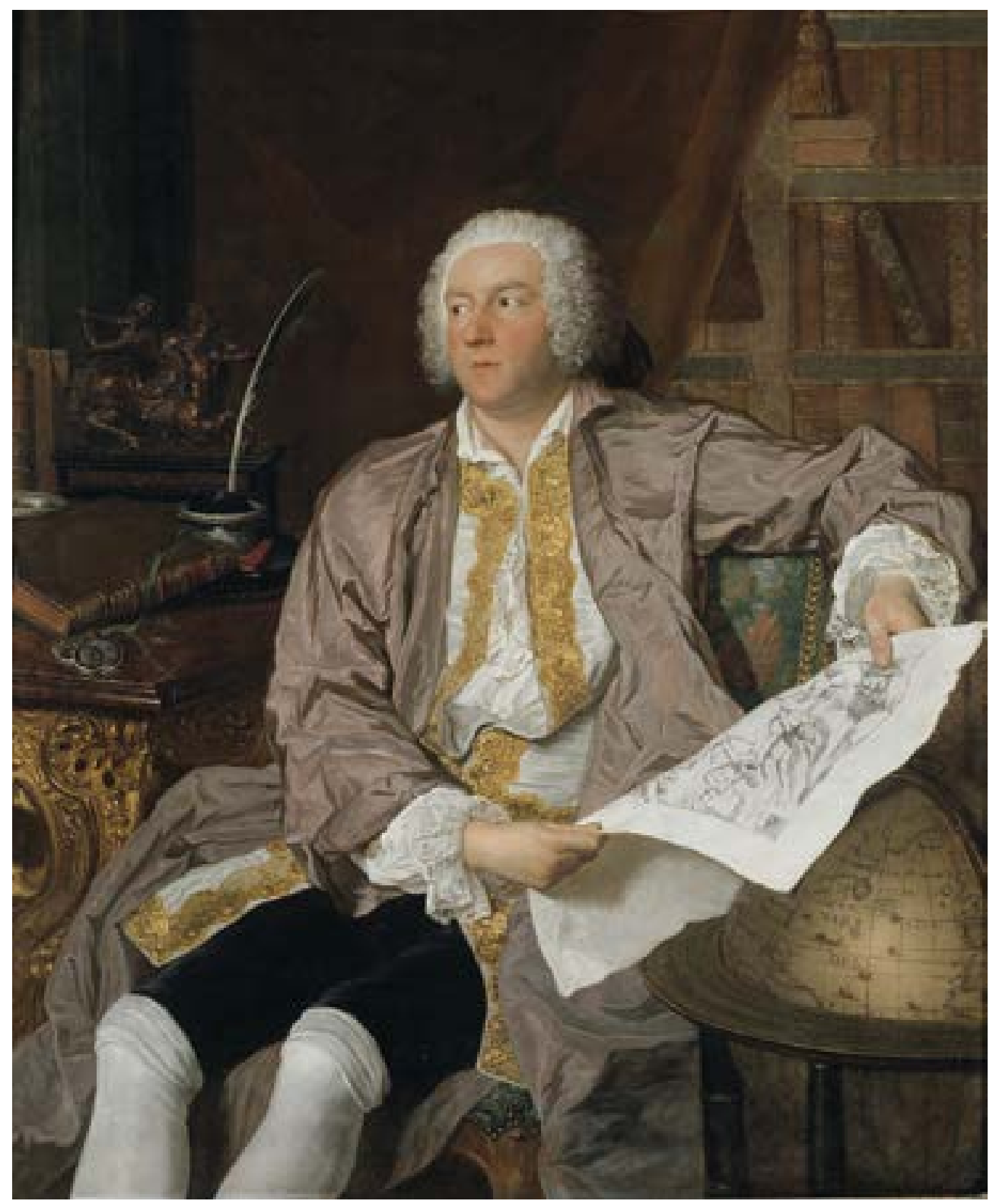

Bild 12. Joseph Aved, Greve Carl Gustaf Tessin (1695-1770). Foto: Nationalmuseum. Hattledaren Tessin var en av Vetenskapsakademiens högst uppsatta mecenater. 
naturalhistorikern och Linnélärjungen Pehr Kalms nordamerikanska resa. Under den gustavianska eran förbigicks huvudsakligen riksdagen med tystnad. ${ }^{665}$

De frihetstida talen var angelägna om att appropriera hattpartiets ledarskikt och ta del av dess karisma. Jennings illustrerade Vetenskapsakademiens ansträngningar för det allmänna bästa och för byggandet av Trollhätte kanal med "vår TESSIN, vår EKEBLAD, vår LIEVEN, vår EHRENSVÄRD", som energiskt sökte fullända det enda sentida projekt som rätteligen kunde jämställas med de driftiga romarnas. Ett antal ledamöter kan förmodas ha anspelat på samma skikt av prominenta hattar som Jennings ringade in. Det hette att åtskilliga av landets högsta män höll ordförandeposten för hedervärd och att den utan hänsyn till samhällsställning kunde växla mellan "en af Riksens ypperste" och någon från medelståndet. ${ }^{666}$ Akademien hade många "purpurklädda Herrar" - det vill säga makthavare - i sina led och vid ett tillfälle var glädjande nog över hälften av de nya riksråden medlemmar i organisationen. Abraham Bäck framhöll de höga herrarnas intresse för allt som kunde gagna fäderneslandet, inte minst den samhällsnyttiga Vetenskapsakademien, vars verksamhet de utgjorde en integrerad del av: "Vi äre så lyckelige at hafva Riksens höga Män i detta vårt Samhälde. En har hedrat Academien med sit arbete, och vi fägne oss at se hans namn i våra handlingar. En har icke längesedan behagat anföra detta vitra Sällskapet, och gifver oss dageliga prof, det [att] han icke mindre hägnar Vetenskaper, än han sjelf är kännare af dem. Det är Honom som vi hafve til en stor del at tacka, för det snille och Vett begynner hos oss lysa up utur mörkret." ${ }^{\prime 67}$

Ledamöterna närmade sig också hattledningen med hjälp av smicker. De förkunnade att regeringen var patriotisk och vaksam på välfärden, liksom att vetenskaper och konster vantrivdes utan högt beskydd och att svenskarna borde anse sig lyckliga som genom regeringens prisvärda agerande fick uppleva en så värdefull fördel; framtida generationer skulle lovorda dem som oförtröttligt bemödat sig om förbättring. Carl Fredrik Adelcrantz jämförde indirekt riksråden med Jean Baptiste Colbert och Agrippa. Han slog fast att Sveriges erfarna riksråd givit de fria konsterna gedigna prov på sitt kraftfulla stöd och upplysta tänkande, 
samt att riksdagens åtgärder för dessa konsters förbättring snart skulle ge allmänheten ("det Allmänna") en ny anledning att berömma regeringens strävan efter rikets sanna väl. ${ }^{668}$

Även de gustavianska presidietalen komplimenterade och gjorde anspråk på ledande politiker och ämbetsmän. Vetenskapsakademien beskrevs som en samlingspunkt för Sveriges mest framstående och lärda män, och som ett sammanhang där de förra tävlade om att föra vetenskaperna inför tronen. Akademien hade lyckan och turen att samla många höga herrar, som alltid ville landets bästa och upprepade gånger demonstrerat sin entusiasm för vetenskaperna. Dessa var "både på snillets och hjertats sida vördnadsvärda" och fann i Vetenskapsakademien "sin yppersta vederqvickelse under ledigheten från ämbetsbördor". De hade inte försummat seden att hålla tal vid nedläggandet av ordförandeskapet, ett ämbete som sannerligen var viktigt när det bekläddes av makthavare som kunde utverka nytta och förmåner åt sammanslutningen. Eric Prosperin förklarade att det aldrig saknats vetenskapsälskare bland rikets förnämligaste män och att akademien kunde skatta sig lycklig i ett läge då dessa "ej tro sin Purpur lida därigenom, at de räkna Sig för våra Medbröder”. De lärda fick nödvändig kunskap om världen genom umgänget med dem, och purpurns likställande med vadmalen gav allmänheten utmärkta exempel på högaktning av vetande och genuin förtjänst, varvid den inre äran tillerkändes lika stort värde som sina yttre attribut. ${ }^{669}$

Flera hattpolitiker gjordes individuellt till föremål för smicker och appropriering. Till dem hörde Henning Adolph Gyllenborg, vilken karakteriserades som en vetenskapsälskare och beskyddare av akademien. Han besannade enligt uppgift fullt ut den patriotiska flit för vetenskaperna, fäderneslandet och nyttiga anstalter som allmänt ansågs vara nästan medfödd hos personer med namnet Gyllenborg. Carl Fredrik Scheffer befanns vara en av de män som borgade för rikets välgång genom sina handlingar och genom att värdera sina höga ämbeten uteslutande utifrån deras förmåga att bidra till det gemensamma bästa. Detta synsätt färgade allt han företog sig, också i förhållande till de lärda och Vetenskapsakademien. ${ }^{670}$ Tessin var inte bara "Rikets stora Man" utan även Vetenskapsakademiens höga ledamot och "uplyste Lärdoms-älskare", vars 
uppmuntrande närvaro fattades organisationen när han inte längre bodde i Stockholm. Presidietalen framställde honom som den främsta källan till akademiens kraft och lyster, som ett geni och ett föredöme för de övriga medlemmarna och som upphovsmannen bakom de oskattbara brev till kronprins Gustav sammanslutningen publicerat. ${ }^{671}$ Höpken tillskrevs egenskaper som förnuft, flit, vetenskaplig böjelse och litterär eminens. Sandels tog upp den tillgivenhet och tacksamhet ledamöterna kände för att han hade lagt grunden till Vetenskapsakademiens förvaltning och framgång; han älskades av och älskade akademien, efterfrågades som ordförande och sekreterare och förgyllde sekreterarposten genom att utgöra dess förste innehavare. Det var synnerligen glädjande att såväl Höpken som hans medgrundare Linné ännu fanns i livet. Under mössornas styre berömde Bengt Bergius dels Cederhielm, dels Höpken, som kallades Vetenskapsakademiens "stora Stiftare, det än lysande Alpha uti vår Ledamots-längd, hvars Purpur vi mindre vörda, än Dess [hans] dråpeliga [förträffliga] egenskaper och förtjenster" ${ }^{672}$

Det hände att mössor som Sten Carl Bielke, det före detta riksrådet Gustaf Bonde och Matthias Alexander von Ungern-Sternberg behandlades på samma sätt som sina politiska meningsmotståndare. Till exempel framhävdes Bondes beskydd av akademien och vetenskaperna, som han uppgavs älska och ägna sig åt under lediga stunder. I samband med Bonde gjordes iakttagelsen att höga herrars ära fördubblades av att de hyste kärlek till och bedrev vetenskaper. ${ }^{673}$ När mössorna satt vid makten uttryckte Rosenadler sin glädje över att få efterträdas som preses av en sådan stor herre som Löwenhielm och över att medlemmarnas samfällda val av honom lyckligen infriats. ${ }^{674}$

De enskilda gustavianska politiker och ämbetsmän som presidietalen smickrade och markerade närhet till hade många gånger ett förflutet $\mathrm{i}$ hattväldet. Fastän frihetstiden utsattes för hård kritik förkastades alltså inte periodens individuella politiska aktörer, som ofta kom att gå den nya regimens ärenden. ${ }^{675}$ Carl Fredrik Scheffers strävsamhet för näringarna, konsterna, vetenskaperna och Vetenskapsakademien lyftes fram, och det fastställdes att en gynnsam framtid aldrig varit mer tryggad eftersom rikets välfärd nu vilade i så pålitliga händer. Sven Bunge, en skyddsling till bröderna Carl Fredrik och Ulric Scheffer, sades besitta 
ett välbekant ädelt tänkande som säkerställde hans stöd till akademien, vars goda tillstånd hänfördes till både Gustav III och vetenskapsälskarna kring tronen, det vill säga högt uppsatta figurer som Bunge. ${ }^{676}$ Andra tidigare hattar som komplimenterades och approprierades var Matthias Benzelstierna, riksrådet Melcher Falkenberg, Jean George Lillienberg, Carl Rudenschöld och Carl Sparre. ${ }^{677}$

Till denna kategori hörde också Höpken, vilken som förut framför allt associerades med Vetenskapsakademiens tillkomstskede. Det påtalades att Höpken hade stiftat akademiens visa lagar och var lycklig nog att få se det nyttiga han planterat bära avsedd frukt. Sammanslutningen delade denna tillfredsställelse med sin förträfflige grundare, som fortfarande lände akademien till heder och kunde hålla efter sin älskade skapelse ${ }^{678}$ Rosenstein den yngre gestaltade strax efter Höpkens död i maj 1789 honom som en tacksamt ihågkommen välgörare och beskyddare:

När blifver tiden för oss, at icke känna och nämna denna förlust? När, at icke sakna et Snille, sällsynt, djupt, skarpt, eldigt och starkt, äfven under ålderdomens tiltagande bräckligheter? när, at icke sakna hans kunskaper, mogne, vidsträckte, uplysande? när, hans ömhet för Academien, hans verksamma nit, hans upmuntrande närvaro? när, hans kärlek för vetenskaperne, icke tilgjord, men upriktig? när, det beskydd han lemnade deras Idkare? et beskydd som de utan rodnad kunde emottaga, efter[som] det gafs utan högmod [...] och när et Tidehvarf upkommer, som icke delar vårt anspråk at äga Grefve HÖPKEN, så måtte detta Tidehvarf icke känna saknaden genom brist af dess [hans] Likar, icke klaga at dess [hans] efterdöme varit utan verkan. ${ }^{679}$

Inte alla politiker och ämbetsmän som berömdes och relaterades till den gustavianska Vetenskapsakademien hade en bakgrund i hattarnas krets. Bland dem som saknade en sådan förankring märks hovanknutna figurer som Nils Adam Bielke och den framlidne hovsekreteraren Pehr Rydman, före detta mössor som Lilliestråle samt personer med vag koppling till frihetstidens politiska liv, som statssekreterarna Elis Schröderheim (Schröder) och Johan Gustaf von Carlson. ${ }^{680}$ Merparten av dem som approprierades och smickrades tillhörde likafullt de 
gamla hattnätverken, som verkar ha behållit mycket av sin vitalitet efter statsvälvningen.

Vissa presidietal förmedlade en starkt egalitaristisk uppfattning om Vetenskapsakademien som har givit genljud i den historiska forskningen. ${ }^{681}$ Frihetstida ledamöter deklarerade att presidiet allena utgjorde sammanslutningens högsäte och att medlemmarna ställde sig likvärdigt positiva till högre och till ringare kollegor på ordförandeposten. Lika entusiasm för vetenskaperna utjämnade allt anseende och gjorde alla lika, samtliga turades om att lyda och befalla, oberoende av den sociala rangordningen. Enbart lärdomen var bedömningsgrund i en fri akademi, där envar mättes efter sitt förstånd och sitt uppsåt. Johan Clason upplyste om att Vetenskapsakademien högaktade förtjänst och uteslutande fäste vikt vid flit, förnuft och vetenskap, inte ämbetsvärdighet. Clason anmärkte emellertid samtidigt att han efterträtt den högt uppsatte greve Piper som preses. Andra ordförande vittnade om hur hedersamt det var att bli upphöjd till en framträdande position av "Höga och Visa Män” och om att Clas Ekeblads maka Eva, akademiens enda kvinnliga ledamot under 1700-talet, förtjänade titeln rikets yppersta kvinna lika mycket för sina egenskaper som för sitt förnämliga stånd. ${ }^{682}$

Vetenskapsakademiens egalitarism förblev ett tema under den gustavianska tiden. Presidietal gjorde gällande att förtjänst endast utgick från strävsamhet, förstånd och vetenskap, inte från slumpmässiga eller tillfälliga faktorer som börd, ålder och ämbetsvärdighet. Akademiens snille och vett hade sedan dess grundande dragit till sig "äfven de högste Konungens och Rikets Männ, at här lika som glömma sin Ätt, sin Höghet och sina stora Värf, at blanda sig ibland lägre Medborgare, och at taga nöje i umgänge ibland sådane, som kallas Vetenskapers Söner”. Sveriges högsta herrar tävlade med anspråkslösa vetenskapsidkare och presides hämtades från båda grupperna. ${ }^{683}$

Som det föreliggande avsnittet visat intog samhällshierarkin trots allt en framskjuten plats i Vetenskapsakademien; traditionalistiskt tänkande samexisterade och överlappade med meritokratiskt. ${ }^{684}$ Denna dubbelhet kan förbindas med Jacob Orrjes iakttagelse att den tidigmoderna periodens lärda mekaniker skulle vara såväl fria och socialt gränsöverskridande aktörer som lojala och undergivna ämbetsmän i ett hierar- 
kiskt system. Eftersom deras gränsöverskridanden var förväntade och ansågs vara nyttiga för det allmänna betraktades de inte som ett hot mot det bestående. ${ }^{685}$ Samma synsätt tycks ha varit aktuellt i akademien.

Karisman som flöt ur organisationens egna göranden korresponderade mot det meritokratiska idealet och karisman som härrörde från samhällsledningen mot den nedärvda sociala rangordningen. Det är frestande att betrakta den senare som överordnad den förra.

\section{Övertalning och kritik}

En viktig aspekt av Vetenskapsakademiens interaktion med samhällsledningen var ledamöternas försök att påverka den senare i vissa riktningar, som regel till att ta sig an olika företeelser, verksamheter och näringar. Dessa försök kunde vara direkta och distinkta, som när ett presidietal hävdade att en regerings huvudansvar bestod i att öka befolkningen och sätta näringsmedlen i rörelse, eller som när akademien enligt ett tal väntade sig att en ledamots insikter skulle ges en särställning i en lagrevision. Övertalningen kunde också vara mer indirekt och förtäckt, som när ett av sekreterarens svar betonade vetenskapernas nytta inom lagstiftningen, i synnerhet med avseende på ekonomiska författningar, vilkas oundgängliga rådgivare de var: "Ju mera Lagstiftaren [...] är af goda kunskaper uplyst, och ju närmare han följer Naturen, desto mera välgrundadt och varaktigt blifver hans verk." Ett annat belysande exempel på mer försiktig övertalning återfinns i en utläggning om ansatser att stimulera handslöjder som bringat välstånd och ökat överhetens makt utomlands. Även om Sveriges överhet hade premierat ett antal slöjder fortfor metallproduktionen att vara eftersatt; det fanns dock hopp om att den skulle få samma omtanke. ${ }^{686}$

Påverkansförsöken kunde vara nog så påtagliga. Rosenstein den yngre var förvissad om att hans uttolkning av folkens rättigheter tilltalade en rättvis och upplyst regering. Han informerade makthavarna om tre sätt att förebygga "folkyra": att styra folket väl och göra det lyckligt, att successivt upphäva vad som var oskäligt och rätteligen kunde kritiseras samt att upplysa menigheten. Han frågade retoriskt varför dessa åtgärder inte prövades när inga andra förslog och ansåg de styrande som vidtog 
dem vara välsignade. Rosenstein konstaterade vidare att det tillföll de mäktiga, primärt regenten, att uppdaga den odödliga och nyttiga sanningen; detta var fursten skyldig både sin egen ära och sitt folk, vilket hade rätt till sällhet. Gustav Vasa åberopades som en positiv förebild medan den spanske konungen Filip II och påven Sixtus V, vilka lönlöst motarbetat reformationen, fungerade som avskräckande exempla. Resonemanget utmynnade i en rättfram uppmaning till samtidens monarker, främst Gustav III: "Konungar! I [ni], som viljen finna et rum i Minnets Tempel, väljen emellan GUSTAFS [Vasa] eller PHILIPS och SIXTI odödlighet. Valet bör icke blifva eder svårt." ${ }^{\prime 67}$ Den förste Gustaven användes här för att övertala den tredje i en subversiv anspelning på regimens självbild och historiebruk.

Carl Fredrik Scheffer tog avstånd från autokrati när han observerade att alla måste frukta för sin säkerhet i samhällen där envåldshärskarens godtycke var grundlagen och där ett enda felsteg från den självtillräcklige fursten kunde förstöra helhetens väl. Kejsartidens Rom fick tjäna som ett varnande och 1700-talets Kina som ett föredömligt exempel. Kinesernas begrepp om ömsesidiga rättigheter och skyldigheter ledde enligt Scheffer till harmoni i form av det mest obegränsade välde och den mest fullständiga undergivenhet i världen. Deras kejsare sågs och upplevde sig själv som en far för folket, vars bästa utgjorde hans enda mål. ${ }^{688}$ Måltavlan för argumentationen mot envälde var med tanke på att Scheffer höll sitt presidietal just efter statsvälvningen rimligen Gustav III, som därmed avråddes från att försöka tillvälla sig otillbörlig makt.

Scheffer underströk också fredens fördelaktighet; den var en förutsättning för ett lycksaligt samhälle och vid sidan av säkerheten allt som behövdes för att människan skulle kunna nyttja sina förmågor. Han förklarade i linje med det att Gustav III förstod att krig fördes i självförsvar, att förbättrandet av fäderneslandet gav mer status än erövringar och att sann ära ställde krav på en fridsam hållning mot grannländerna. Tillsammans med monarkens personlighet och fredliga lagar borgade dessa Gustavs insikter för en lugn regeringsperiod. Samtidigt tålde konungen inte att bli förolämpad. ${ }^{689}$ Hela denna diskussion, i synnerhet den sista kommentaren, bör läsas mot bakgrund av att Sverige vid tidpunkten för Scheffers tal befann sig i en utsatt situation och hotades 
av ett militärt ingripande från Danmark och Ryssland, som ogillade konungens politiska nyordning. ${ }^{690}$

Övertalningen gällde inte minst vetenskaperna. Till exempel diskuterade Faggot behovet av fler lantmätare med bättre materiella villkor som skulle fullkomna deras för Kongl Maj:t och riket nyttiga konst. Det allmänna hade en skyldighet att underhålla Lantmäteriverket om det skulle förbli livaktigt, något som Faggot underdånigt framfört "å hög ort". Andra ledamöter målade med bredare penseldrag. Adelcrantz menade att det var till stor lycka för de fria konsterna "när deras refvor blifva uptäkte af sådane Män, som icke allenast äga de uplyste egenskaper, som fordras til deras kännedom, utan ock magt och mod dem samma at bota. Så väsendteliga förändringar äro icke et ögnablicks verk; men en vis Regering tvingar tiden, och förekommer Allmänhetens hopp". ${ }^{691}$

Vetenskapsakademiens läkare var särskilt tydliga med vad de ville att makthavarna skulle uträtta. Zacharias Johan Strandberg tillskrev dem som helar kroppen första rummet i mänskligheten och argumenterade för mer resurser från rikets ledning: "konsten ökes ej utan kostnad. Gifven oss Hospitaler så inrättade, som vi vele. Gifven åt vissa af oss tilräckeligt underhåll, på det vi, som nästan endast måtte arbeta för födan, må då kunna arbeta på vår vetenskaps tilväxt.” Herman Schützercrantz vände sig delvis till de besuttna när han skildrade den franske konungen Ludvig XV:s stöd till en kirurgisk akademi och hur en av dennes livläkare donerat medel till kirurgin: "Kunna väl rikedomar ädelmodigare användas? Önskeligt vore, at vittre och förmögne, hvar och en i sitt förehafvande, fölgde et så lysande efterdöme!" Han adresserade sannolikt makthavarna när han meddelade att svensk kirurgi under en upplyst regering så småningom skulle nå Frankrikes nivå, samt att inhemska kirurger utan ersättning börjat lära ut sitt ämne och med ringa biträde skulle kunna få till stånd en lika förmånlig inrättning som Paris kirurgiska akademi. Han avrundade betecknande nog sin redogörelse med en hyllning till vetenskapsfursten Adolf Fredrik och reflektionen att önskningar tillkommer alla medan deras förverkligande är avhängigt de mäktiga. ${ }^{692}$

Läkaren Casten Rönnow tillkännagav medicinens överhöghet och efterfrågade ett större lasarett i Stockholm efter fransk förlaga, vilket 
hela Sverige skulle bekosta. Han vände sig likväl framför allt till Gustav III, som givet sin kärlek till vetenskaperna och folket torde hitta sätt att främja medicinen i sitt land. Sjukhusen var ytterst nyttiga och oumbärliga för Sveriges invånare, kungahuset inräknat, och då läkekonsten strävade efter att rädda såväl monarkens lojala undersåtar som honom själv, förtjänade den hans beskydd. Gustavs belöning skulle bli både samtida och framtida lovord. Wargentins svar ställde sig bakom talets budskap och uppgav att Vetenskapsakademien inte betvivlade att konungen skulle leva upp till Rönnows och akademiens önskemål. ${ }^{693}$

De övertalningsförsök som riktade sig till konungarna kan i flera fall ses som ett uttryck för en furstespeglande tradition. Bengt Ferrner föreställde sig en ideal regent som styrd av förnuft och erfarenhet lade all sin möda på att göra folket lysande och lyckligt. Den upplyste härskaren kom till rätta med fördomen att klimatet förfördelade hans folk genom att uppfostra undersåtarna till ljus och förstånd. Även om han själv inte fick bevittna slutresultatet av sin gärning var det de efterkommandes omdöme som betydde något för en stor monark, och de skulle frambära tacksamhetsoffer till den som räddat dem från förtryckande fördomar. Ferrner underlät inte att ge besked om mera exakt vem han hade i åtanke: "Jag känner en sådan Regent, och de, som komma efter mig, finna lätteligen igen honom af de spår, som han lemnat efter sig." Enligt Sandels beaktade en klok monark att vetenskaper och hushållning gynnade rikets välfärd och ära. Utan bistånd mådde vetenskaperna inte bättre än själen i en sjuk eller misskött kropp, och eftersom en furste formade sitt folk innebar dennes åsidosättande av dem att de nedvärderades, försvann ur blickfånget och inte kunde dras fram ur sina gömslen utan speciella hedersbevis och förmåner. Vetenskapliga sammanslutningars bidrag till lärdomen berodde på de mäktigas beskydd och ett anseende som vanns genom att makten trivdes i dem. Vetenskapsakademiens bedrifter var följaktligen en konsekvens av det stöd den fătt, och dess astronomiska observatorium åskådliggjorde regenters möjligheter att befordra nyttiga företeelser. Nils Adam Bielke ansåg att stränghet utan nåd var hårdhet och kunde urarta $\mathrm{i}$ tyranni, men likställde samtidigt godhet utan stränghet med svaghet och bedömde denna brist vara mer riskabel för samhället. Ordning måste råda, författningar implementeras 
med eftertryck och ett ostyrigt folk ibland tuktas med ovarsammare metoder. Wargentins svar till Bielke inleddes med ett citat från den medeltida furstespegeln Konunga- och höfdingastyrelsen om att en rik menighet hedrade och en fattig vanhedrade regenten, vilket sekreteraren instämde med. ${ }^{694}$

Bielke och Wargentin var inte ensamma om att väva in den svenska historien i sina påverkansförsök. Till exempel sökte Faggot troligen influera Adolf Fredrik då han tog upp tidigare monarkers intresse för lantmäteriet och geografikunskapen. Den dåvarande kronprinsen hade "med blodet ärft sina Stora företrädares vishet ock dygd"; han kunde inte annat än främja deras avsikter på området och därigenom sin och Sveriges gemensamma välmåga. Ett övertalningsförsök i historisk skrud går att urskilja även hos historikern Anders Anton von Stiernman (From), som anförde att Oden vetat att "klokhet, ädla Vettenskaper, höga och nyttiga tings älskande och befrämiande, äro Regenters klaraste kikare, alla länders dyrbaresta skatter och ägodelar, och att uppå dem fotar sig bägges sällhet, styrkia och förkofring" ${ }^{695}$ En del utsagor om förflutna och samtida utländska furstar kan också antas ha haft en dimension av övertalning, som när det hette att Europas monarker tävlade om att driva konster och vetenskaper så långt som möjligt, eller att Fredrik III av Danmark insett att regenters omsorg om vetenskaperna var det säkraste sättet att åstadkomma deras blomstring. ${ }^{696}$

Det hände att de styrande mer eller mindre explicit ifrågasattes i presidietalen. Ulric Rudenschöld hänförde böndernas alltför vidlyftiga skogsbruk till myndigheternas bristfälliga reglering. Erik Salander slog fast att ämbetsmännen inte alltid besatt nödvändiga kunskaper om slöjderna och att undermåliga slöjdprodukter var en följd av sanktionerad oordning, vilken liknades vid ogräs och skylldes på de som hade makt men underlät att agera och teg och tillät. Han drog en parallell till hur okontrollerade barn hemföll åt självsvåld och skadade såväl sig själva som andra - något föräldrarna bar ansvaret för. ${ }^{697}$

Rosenstein den yngre var en av de mest kritiskt sinnade ledamöterna. Han tog explicit avstånd från maktfullkomliga furstar i ett resonemang som tidsligt sammanföll med Gustav III:s förenings- och säkerhetsakt: 
Intet är naturligare, än at Konungar skola älska sin magt. Men huru många Regenter hafva icke öfverdrifvit sina anspråk, och lekt med människors rättigheter derföre, at de icke känt dessa senare. Konung JACOB I. [av Storbritannien] trodde såsom en Tros-artikel, at dess [hans] magt var ensamt af Gudomligt uphof och oinskränkt; at dess undersåtare hade en ovilkorlig skyldighet at lyda utan minsta rättighet til gensägelse eller motstånd. Om han haft en annan öfvertygelse, är troligt, at denna verkeligen milda och välmenande Konung icke genom obilliga [orättmätiga] påståenden lagt grund til sin Sons och hela sin ätts olycka.

Argumentationen kan tolkas som en förmaning till Gustav med anledning av hans allt större maktfullkomlighet. Samma perspektiv går att anlägga på fler inslag hos Rosenstein, exempelvis hans teser att makt utan motbalans är farlig och att återhållsamhet utgör ett av de band upplysningen lägger på människorna och en anhalt på vägen mot dygden. Han hänvisade inte för inte tydligt till den pågående inhemska debatten om kungamaktens omfattning då han uppmärksammade svenskarnas kännedom om att folket borde beskatta sig självt, en värdefull rättighet som fortfarande var aktuell. Denna betraktelse alluderade på att konungen genom förenings- och säkerhetsakten ursprungligen tänkte ge sig själv rätt att via ett extraordinärt riksdagsutskott besluta om skatter när han behövde ytterligare medel, en förändring som emellertid aldrig blev av. ${ }^{698}$

Rosenstein tog spjärn mot historien för att underbygga sina politiska satser. Han framställde Julius Caesar som en demagog, brottsling och förtryckare, och gestaltade dennes motståndare som frihetens försvarare. Rosenstein hoppades på att få bevittna födelsen av Theopomper som hörsammade "Statens och Medborgarnes rättmätiga fordringar"; en fotnot klargjorde att Theopompos var en spartansk monark som begränsade kungamakten och förankrade den i lagarna. Samtidigt trodde han att envåldshärskare som den romerske kejsaren Nero, Kristian II av Danmark eller Henrik VII av England inte var gångbara i samtiden. Fastän människan ännu bar på despotismens frön skulle det gängse tänkandet avhålla den grymmaste regent från att ta efter dessa suveräner. Upplysningen fättrade monarkerna, vilket tillsammans med den 
furstliga dygden gjorde att det europeiska land som uppvisade den mest oinskränkta kungamakten, Frankrike, under en rad konungar styrts med lika mycket humanitet, mildhet och rättvisa som de flesta riken. Rosenstein försvarade vidare det befintliga gustavianska systemet. Han fann att Sverige inåt behövde "all frihetens varsamhet, trygghet och säkerhet" och utåt "mot Mägtiga Grannar all Enväldets enkelhet, skyndsamhet, samdrägt och styrka". För att landet inte skulle slitas sönder krävdes "en stark motvigt i en endas hand". ${ }^{699}$ Kritiken av regimen och det bestående hade sina gränser; Gustav III:s statsvälvning var legitim, men hans förenings- och säkerhetsakt var det inte eftersom den gjorde kungamakten alltför dominerande.

Ett angrepp på de kungliga maktambitionerna går även att utläsa i ett tal av Axel Magnus von Arbin, som 1787 riktade hård kritik mot Karl XI:s "stora hvälfning" i grundlagen, alltså det karolinska enväldets införande. Karls handlande uppgavs ha motiverats av äregirighet, eventuellt också av hämndlystnad, och "uphögt Svea välde i et vådeligt välstånd, i anseende til därigenom verkade Inrikes gäsningar och utrikes Magters, antingen misstroende, eller afund". ${ }^{700}$ Mellan raderna skymtar det sengustavianska Sveriges såväl inre som yttre spänningar, året innan konungens ryska krig bröt ut.

Hattarna startade två misslyckade och impopulära revanschkrig, först mot Ryssland (1741-43), sedan mot Preussen (1757-62). Kriget mot Ryssland var ett försök att dra fördel av att olika fraktioner där rivaliserade om makten och utkämpades med franskt stöd. Efterspelet inbegrep landavträdelser från svensk sida och att det ryska hovet dikterade valet av Adolf Fredrik till Fredrik I:s efterträdare. Pommerska kriget utgjorde ett led i det världsomspännande sjuårskriget, vars huvudkontrahenter var Storbritannien och hattpartiets allierade Frankrike, som förlorade den segdragna kraftmätningen. Hattregeringen inträdde i konflikten efter påtryckningar från fransk och österrikisk sida med målet att återta de områden som avträtts till Preussen 1720. En separatfred utan gränsändring kunde slutas genom att Lovisa Ulrika å Sveriges vägnar förhandlade med sin bror Fredrik II. ${ }^{701}$

Det är ofta svårt att avgöra huruvida allmänt hållna uttalanden om fred och krig i presidietalen före, under och efter hattarnas krigspro- 
jekt handlade om deras utrikespolitik, stora nordiska kriget eller en principiell och kosmopolitiskt färgad ståndpunkt. Vissa utsagor avsåg dock helt klart hattregimens krig. Bäck berörde den farliga smitta, Uppsalafebern, som det ryska kriget vållat och Claes Grill noterade de förluster landet lidit när det under samma krig tvingats nyttja främmande skepp för import av livsmedel. Svenskpomraren Johan Fredrik Krygers hemtrakter var pommerska krigets skådeplats. Han gav prov på en pacifistisk tendens året efter dess utbrott, då han ondgjorde sig över väpnade konflikters negativa effekter. Kryger angav visserligen att "äldre och nyare förbindelser" berättigade att fria samhällen förde krig, men "endast för freden [sic] skul", varför ett sådant företag inte blev långvarigt. ${ }^{702}$

Gustav III:s ryska krig (1788-90) var liksom hattarnas båda krig kontroversiellt. Det syftade i likhet med dem till återerövrande av förlorat territorium och hade inte heller en gynnsam utgång för Sverige. ${ }^{703}$ Rosenstein den yngre, som opponerade sig mot konflikten, förkunnade att monarker slösat bort undersåtarnas liv och rikedomar på fruktlösa och onödiga krig, även om de ofta varit ute efter att befordra det allmännas väl jämte sin egen ära. De militära dygderna måste ständigt näras, varför det var bättre att bygga ett rike på tillväxande industri; krigsorienterade länder gick sitt fördärv till mötes. ${ }^{704}$

Kryger och Rosenstein till trots var motståndet mot hattarnas och Gustav III:s krig lika litet som övrig kritik av makten framträdande i presidietalen, vilket förstärker intrycket av Vetenskapsakademien som dess lojala bundsförvant.

Detta kapitel har skärskådat Vetenskapsakademiens självbild och akademiens interaktion med samhällsledningen. Vetenskapsakademien beskrevs ofta som ett samhälle med lagar, och flera av presidietalen laborerade med en lärd och en politisk gemenskap som i någon utsträckning speglade varandra och var diskursivt jämställda. Sammanslutningens och medlemmarnas nyttosträvan utgjorde ett tema genom hela undersökningsperioden. Presidietalens nytta, akademiens befintliga eller framtida bedrifter samt det omgivande samhällets tacksamhetsskuld gentemot 
den och lärdomen diskuterades. Vetenskapsakademiens patriotiska nit var ett annat ledmotiv, samtidigt som organisationens arbete i mänsklighetens tjänst togs upp. Vetenskapen framställdes som gynnsam för fäderneslandet, andra riken och hela det mänskliga släktet, och som essentiell för själva människoblivandet. Ett tredje återkommande ämne var akademiens nationella och internationella anseende.

Vetenskapsakademiens nyttoansträngningar, patriotism och hantering av värdefull kunskap gav den en bildlig centralitet i samhällsgemenskapen. Akademien kan mot bakgrund av detta ses som en arena där karisma genererades i kraft av inrättningens inveckling med samhället och dess ödesfrågor. Vetenskapsakademien fanns i samhällets mitt tillsammans med makthavarna, medan föreställningarna om vetenskapens nytta för mänskligheten och betydelse för att uppnå status av människa beredde den och akademien en än mer central position i tillvaron. Det framstår därmed bara som följdriktigt att samhällets kunskapsägande kontrasterades mot den okunniga menigheten. Den mest fullödiga yttringen av Vetenskapsakademiens uppfattning om de lärda som en elitgrupp stod Rosenstein den yngre för när han argumenterade för deras medverkan i det politiska styret.

Presidietalen markerade närhet till och approprierade samhällsledningen, varvid Vetenskapsakademien tog del av maktens strålglans och även på det viset placerades i samhällets mitt. Akademien kunde härvid addera till samhällsledningens karisma genom att förstärka den visavi samhället. De nära förbindelserna med makthavarna och eliten framgick på flera sätt: uppräkningar av bemärkta ledamöter inkluderade ämbetsmän, politiker och politiskt inflytelserika näringsidkare; relationen till statsmakten berördes; donationer från elitpersoner, kungligheter och ständerna noterades; mecenaters stora och livgivande inverkan poängterades. Det avtryck monarkerna gjorde på Vetenskapsakademien genom beskydd, uppmuntran och närvaro vid sammankomsterna intog en särställning i presidietalens utläggningar om samhällsledningens främjande av organisationen.

Adolf Fredriks nära förhållande till Vetenskapsakademien påtalades ofta innan det rojalistiska statskuppsförsöket 1756, varefter konungens beskydd marginaliserades fram till dess att de politiska konjunkturerna 
förändrats avsevärt. Under frihetstiden positionerade sig ledamöterna vidare nära ständerna och hattpartiets ledarskikt, vilkas beskydd av akademien lyftes fram. Det synliggjordes att hattledningen som grupp deltog i verksamheten, och ett antal hattar gjordes individuellt till föremål för appropriering medan endast ett fåtal mössor vederfors samma ära. De gustavianska talen gjorde också anspråk på rikets högt uppsatta politiker och ämbetsmän, varav många hade ett förflutet i hattregimen.

En del presidietal förmedlade en utpräglat egalitaristisk syn på Vetenskapsakademien som gått igen inom den historiska forskningen om organisationen. Det föreliggande kapitlet har dock givit vid handen att samhällshierarkin kastade långa skuggor över akademien. Vetenskapsakademien hade förvisso egalitära inslag - till exempel dikterade dess kunskapssyn att alla kunde begripa och bidra till lärdomen - men det innebär inte att sammanslutningen som helhet kan karakteriseras på ett sådant vis. ${ }^{705}$ Det är frestande att betrakta karisman från samhällsledningen, vilken svarade mot den vedertagna sociala ordningen, som överordnad karisman från akademiens egna göranden, vilken svarade mot det meritokratiska idealet.

En viktig aspekt av Vetenskapsakademiens samspel med de styrande var ledamöternas ansatser att påverka dem i vissa riktningar och få dem att ta sig an olika företeelser, verksamheter och näringar. Övertalningen handlade inte minst om vetenskaperna och kan när den riktades till regenterna i flera fall tolkas som ett uttryck för en furstespeglande tradition. Till det kom att presidietal emellanåt utsatte makthavarna för mer eller mindre uttalad kritik. Övertalningsförsöken och ifrågasättandena indikerar en vilja att korrigera och sätta sig över samhällsledningen som överensstämmer med akademiens hävdande av sin och lärdomens framskjutna roll i den mänskliga samlevnaden. Denna vilja var likväl begränsad och underordnad tjänstvilligheten gentemot makten. 